\title{
Urban ornamental plants for sustenance of wild bees (Hymenoptera, Apoidea)
}

\author{
(D) G.Y. Honchar ${ }^{1}, \oplus$ A.M. Gnatiuk ${ }^{2}$ \\ ${ }^{1}$ Institute for Evolutionary Ecology, National Academy of Sciences of Ukraine, Lebedeva str. 37, 03143 Kyiv, Ukraine; apantova@ukr.net \\ 2 M.M. Gryshko National Botanical Garden, National Academy of Sciences of Ukraine, Timiryazyevska str. 1, 01014 Kyiv, Ukraine; \\ colchicum@i.ua
}

Received: 06.04.2020 | Accepted: 26.05.2020 | Published: 30.06 .2020

\begin{abstract}
The aim of our study was to assess the attraction and value of flowering plants at green areas in support and sustenance of wild bees (Hymenoptera, Apoidea) populations in Kyiv. Study objects were the most common flowering ornamental plants of the city and the wild bees visiting their inflorescence during the vegetation season to collect pollen and feed on nectar. The study was conducted at 16 areas of observation and material collection, which include urban parks, M.M. Gryshko National Botanical Garden, green spaces of residential areas, roadsides, etc. Insects were collected following the standard method of catching individual specimens during the spring and summer periods of 2012-2018. Based on the observations, we visualized trophic relations of bees with plants and calculated the biodiversity index of visiting insects for plants. The blossom periods were analyzed using phenological data. Examination of urban green areas revealed ornamental plants that were the most attractive for bees, including more than 35 taxa of 20 families of trees, shrubs, and grassy plants. Bees are superiorly attracted to plants of the genera Rudbeckia, Sedum, Gypsophila, Cerasus, Tagetes, Spiraea, Lonicera, and Aesculus. There is a succession of plant flowering during spring-summer season, which must be considered while planting of greenery. Certain plant species attract insects at each blossom period, for example, Prunus, Rhododendron, Crataegus, Aesculus in spring, most of Asteraceae - in summer. The diversity of blossoming plants is significantly lower at the end of summer and beginning of fall, coinciding with the decreasing flight activity of wild bees. Overall, the studied ornamental plants attract not only the most common species of wild bees but also highly specific and rare species such as Bombus argillaceus and Xylocopa valga, protected by the Red Data Book of Ukraine. We found that blossoming green areas made up of trees, shrubs, and herbs are essential for feeding many species of wild bees and sustaining their populations in urban conditions.
\end{abstract}

Keywords: ornamental plants, wild bees, urban conditions

\section{Introduction}

The urban environment becomes increasingly important to the sustenance of biodiversity, which is critically endangered by the combined effects of intensive agriculture, agrotechnical measures, and use of pesticides (Chiesura, 2004; Winfree et al., 2009; Dearborn \& Kark, 2010; Sanderson \& Huron, 2011). The humankind is now facing the problem of extinction and rapid decline of pollinator populations (Potts et al., 2010), including the wild bees (Hymenoptera, Apoidea). Those insects are considered the best pollinators because they pollinate almost $80 \%$ of flowering plants (Klein et al., 2007; Smitley, 2018).

Botanical gardens, parks, and garden squares are especially significant for the preservation of biodiversity (Hammitt, 2002; 
Mexia et al., 2018). For many plants, there are conditions to grow ex situ in botanical gardens and parks. The general composition of green areas of Kyiv, their protective and purifying functions, esthetic value and conservation significance were described in numerous publications (Cherevchenko et al., 1999; Cherevchenko \& Kuznetsov, 2003; Rubtsova, 2006; Doyko, 2012; Klymenko, 2012; Hatalska \& Kryvenko, 2012; Rogovskiy, 2013; Pikhalo, 2014; Melezhyk, 2015; Matiashuk et al., 2015). Trees and shrubs are essential food sources for bees (Somme et al., 2016). The species composition of trees of urban plantations in Kyiv includes a lot of plants that are attractive to bees: $39.6 \%$ linden, $22.2 \%$ horse chestnut, $4.0 \%$ Norway maple, and nearly $2 \%$ black locust and rowan (Lesnik, 2015). However, their distribution is limited, and flowering is rather short-term. As for shrubs, only 20 of recorded species are decorative bloomers, representing only $6.7 \%$ of all shrub species in collections of the botanical gardens of Kyiv (Oleksiychenko \& Breus, 2013).

The primary factors limiting the sustenance and persistence of wild bee populations are feeding and nesting resources. Places for bees to nest are more or less present in urban biotopes. Species that nest in the soil can use fragments of soil cover at roadsides, garden squares, urban parks; those that use plant material can nest in deadwood in parks and private plots; for those preferring hollows, there are walls of buildings and fences. However, the foraging resources (flowers) are often limited due to the impoverished composition of plants. This fact also negatively impacts the growth and reproduction of bee populations.

Overall, the trophic relations of wild bees have been studied extensively in cities of other countries. Many authors have pointed out the significance of decorative green areas (with blossoming trees, shrubs, and herbs) as foraging resources for bees (Gathmann \& Tscharntke, 2002; Acar et al., 2007; Hennig \& Ghazoul, 2011; Garbuzov \& Ratnieks, 2014; Hausmann et al., 2016; Garbuzov et al., 2017; Lowenstein et al., 2019; Sikora, 2019; Erickson et al., 2020). However, the attractiveness and value of decorative green areas with various plant species to wild bees have not been studied in urban conditions before.
Our work aimed to study the trophic relations of wild bees with flowering plants of the green areas of Kyiv.

\section{Material and methods}

Studies were conducted in Kyiv during the spring and summer seasons of 2012-2018. Model areas were located in the M.M. Gryshko National Botanical Garden of NAS of Ukraine (a significant hotbed of phytodiversity), and urban parks "Feofaniya", "Nyvky", "Peremoha", "Partizans'koi slavy". Also, the ornamental green plantations of residential areas "Teremky 1", "Vynohradar", as well as the avenues, roadsides, stops of civil transport, and road intersections were studied (Fig. 1).

Here, we consider the most common flowering ornamental plants (more than 35 taxa) of green areas and decorative plant compositions of the model territories, in relation to their attractiveness to bees. Bees were collected with an insect net while bees were visiting flowers (Pesenko, 1982). The visited plants and their botanical family membership were recorded. Individual specimens were caught, euthanized with ethyl acetate, and brought to the laboratory for species identification. We chose the most common bee species found in a city from our previously published check-lists of wild bee species (Honchar, 2017; Honchar \& Gnatiuk, 2018; Radchenko \& Honchar, 2019) to determine their trophic relations. In total, around 50 species of wild bees are considered here from the families Colletidae (two species of Colletes Latreille, 1802 and three of Hylaeus Fabricius, 1793), Andrenidae (seven species of Andrena Fabricius, 1775), Halictidae (one species of Nomioides Schenck, 1866, two of Sphecodes Latreille, 1804, two of Seladonia Robertson, 1918, two of Lasioglossum Curtis, 1833, three of Halictus Latreille, 1804, and six of Evylaeus Robertson, 1902), Megachilidae (one species of Heriades Spinola, 1808, two of Osmia Panzer, 1806, one of Anthidium Fabricius, 1804, one of Anthidiellum Cockerell, 1904, three of Megachile Latreille, 1802), Apidae (one of Xylocopa Latreille, 1802, one of Eucera Scopoli, 1770, one of Tetralonia Spinola, 1838, two of Anthophora Latreille, 1803, and eight of Bombus Latreille, 1802). In total, 1041 samples were collected (see Appendix). 


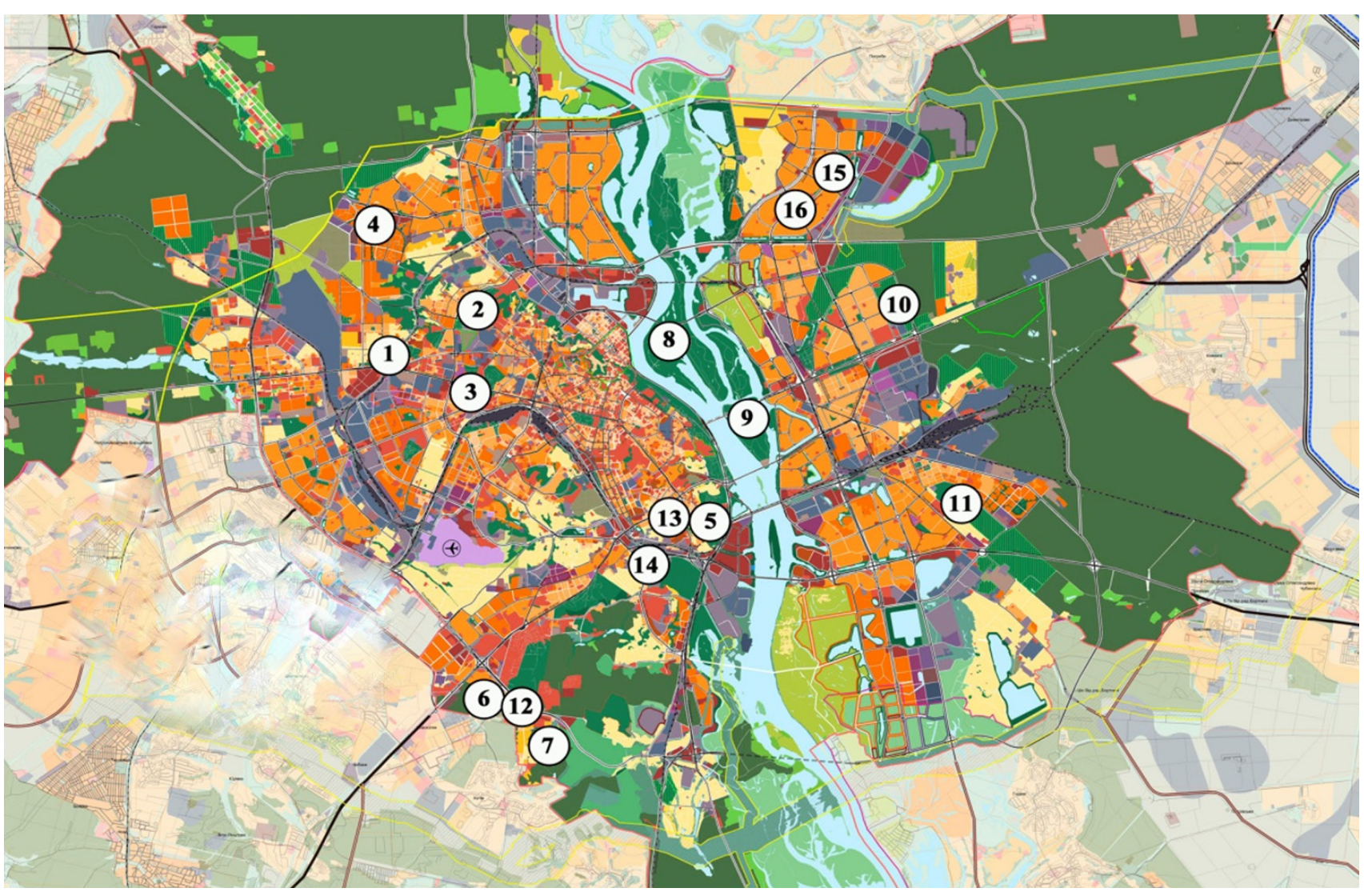

Figure 1. Model areas: 1 - "Babin Yar" park; 2 - "Nyvki" park; 3 - "KPI" park; 4 - "Vinogradar" residential area; 5 - M.M. Gryshko National Botanical Garden; 6 - "Teremki-1" residential area; 7 - "Feofaniya" park; 8 - Trukhaniv island; 9 - Hydropark island; 10 - "Peremoha" park; 11 - "Partizans'koi Slavy" park; 12 - Akademika Zabolotnoho str.; 13 - Druzhby Narodiv blvd.; 14 - Saperno-Slobidska str.; 15 - Zakrevskogo str.; 16 - Mayakovs'koho avn.

The trophic relations were visualized in $\mathrm{R}$ version 3.6.1 ( $\mathrm{R}$ Core Team, 2014) using the "bipartite" package (Dormann, 2011, 2020). Trophic relations between bees and the respective plants are presented graphically. The width of relation on one side indicates the number of visits and diversity of visitors for plants, and on the other side for bees (Figs. 2 \& 3).

We used the diversity index $\mathrm{S}$ for the bee visitors of flowers (Table 1). The index is based on Fisher's $\alpha$ (Fisher et al., 1943; Magurran, 2013; Dormann, 2020).

\section{Results}

The bee species differed by periods of their flight activity and nesting specifics. Some of them build their nests in soil, other - in plant material, for example, members of the family Megachilidae or the genus Hylaeus prefer hollows. There were solitary bees, inquilines (Sphecodes spp.), and eusocial species (Bombus). The main trophic relations that we have observed in the system "bee angiosperm" are represented on Figs. $2 \& 3$.

The bipartite network (Fig. 2 \& 3) constitutes weighted representations of the plant-pollinator interactions. We used the frequency of flower visits by bees as the interaction weight to construct the network. The number of relations and index of diversity for each plant are given in Table 1.

The highest diversity of bee visitors, seen at Figs. $2 \& 3$, is indicated for the genera Spiraea L. (mostly for S. japonica L.f., S. media Schmidt, S. vanhouttei (Briot) Zabel.), Malva L., Prunus L. (Cerasus L.), L., Rhododendron L., Rudbeckia L., Tagetes L., Dahlia L. Representatives of the genus Bombus (B. lapidarius (Linnaeus, 1758), B. lucorum (Linnaeus, 1761), B. terrestris (Linnaeus, 1758), B. pascuorum Scopoli, 1763, and of Hylaeus communis Nylander, 1852, Anthophora plumipes (Pallas, 1772) and a few other taxa were the most frequent visitors of decorative plants in our study (Figs. 2 \& 3). 


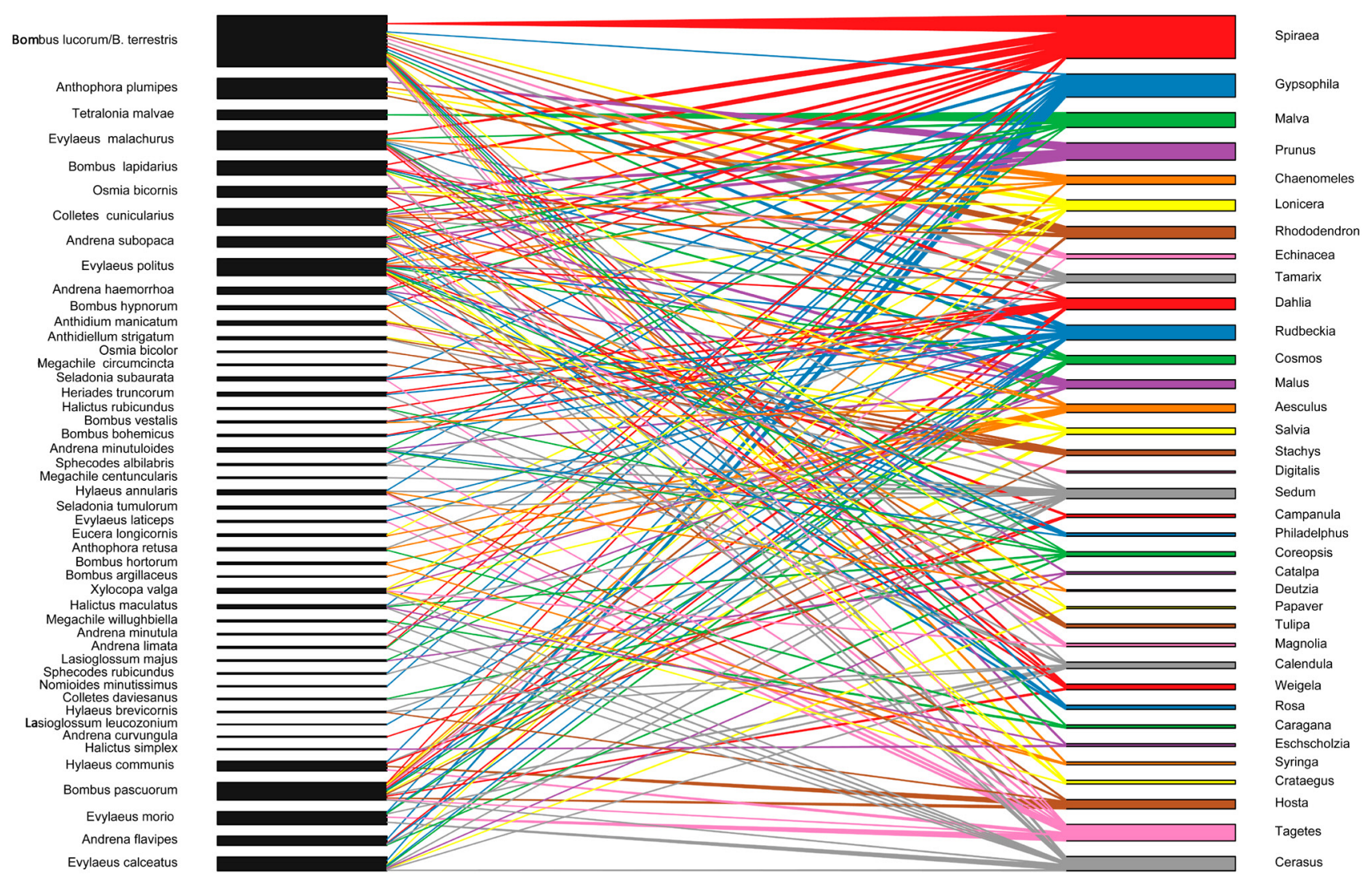

Figure 2. General view of the trophic relations of wild bees with ornamental plants of the urban green areas. The size of boxes is proportional to the total number of visits recorded per species. The thickness of the interaction lines represents the frequency categories of the interactions.

As can be seen from Table 1 and Figs. $2 \& 3$, there are plant species that attract more than 10 wild bee species. However, there are plants such as Spirea, which mostly attract the most common bumblebee species and abundant species of the genus Evylaeus, less so other wild bees. Similarly, flowers of Gypsophila paniculata, Dahlia, and Tagetes attract a significant number of these insect species. However, the visitor diversity index is 3 to 6 in these cases because of the domination of certain species. Some plant species, such as Calendula, Coreopsis, Rudbeckia, Sedum L., Prunus, attract pollinators more evenly. In general, the bee species with higher ecological plasticity dominate in the urban environment, though specific oligolectic pollinators of certain species also are represented (Banaszak-Cibicka \& Żmihorski, 2012; da Rocha-Filho, 2018). Those bees are attracted to plants of the genus Malva (specifically, Tetralonia malvae (Rossi, 1790), bees eat pollen from these flowers), Campanula (to which Andrena curvungula Thomson, 1870 is specialized), Stachys and Digiatalis are pollinated by Anthidium manicatum (Linnaeus, 1758) and Osmia bicolor (Schrank, 1781).

Aesculus hippocastanum L. attracts eight of the most common wild bee species, including two protected by the Red Data Book of Ukraine (Radchenko, 2009; Radchenko et al., 2009), Bombus argillaceus (Scopoli, 1763) and Xylocopa valga Gerstaecker, 1872. Bees of the latter species have a lot of various trophic relations on the studied territory. Fruiting trees of the family Rosaceae that are planted in green areas are also essential for bees in early spring throughout the season, especially in herb-free urban biotopes.

We have found that bees are more attracted to plants from the following 20 families. Families Asteraceae and Rosaceae were exceptionally diverse by the number of plant taxa visited by bees (Table 1; Fig. 4). At the same time, several families which were presented by only one or two genera (such as Tamaricaceae and Sapindaceae) are significant for feeding of wild bees of various species. 


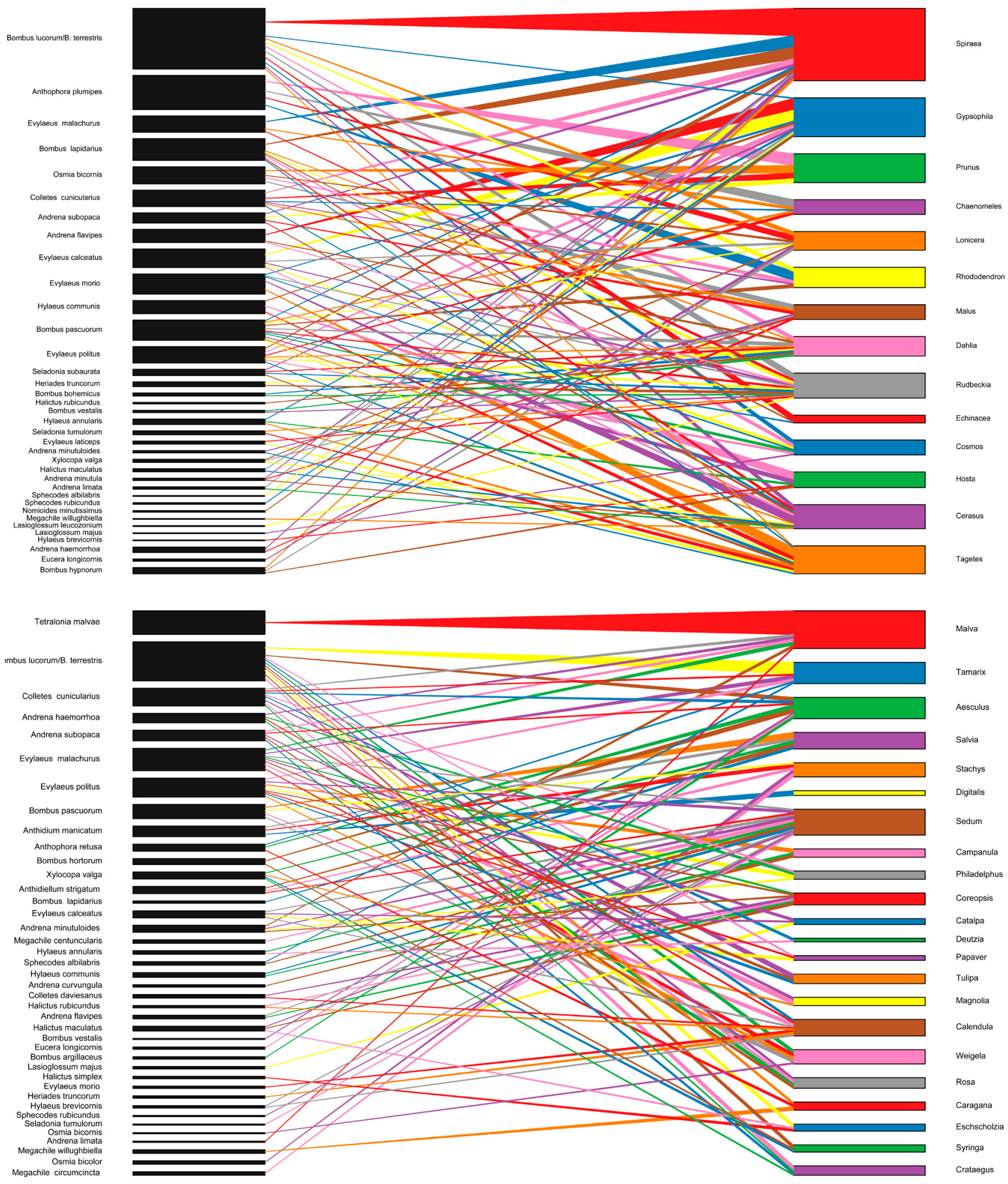

Figure 3. Detailed view of the trophic relations of wild bees with ornamental plants of the urban green areas. The size of boxes is proportional to the total number of visits recorded per species. The thickness of the interaction lines represents the frequency categories of the interactions.

There are seasonal fluctuations in the species diversity of wild bees. Overall, wild bees begin their flight activity in the middle of March though that is notably dependent on weather conditions. The highest level of bee diversity is observed in May and June, then again in early July, and declines in August. During the large-scale distribution and reproduction of bees, the presence of pollen and nectar reserves is critical, affecting the nutritive qualities of feeding resources, and most importantly, the collection of a provision 
Table 1. Diversity of relations of certain decorative plants with bees.

\begin{tabular}{|c|c|c|}
\hline Plant taxa & 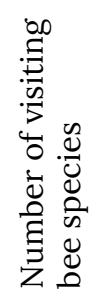 & 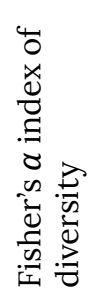 \\
\hline \multicolumn{3}{|l|}{ Asteraceae Bercht. \& J. Presl } \\
\hline Calendula L. & 8 & 8.85 \\
\hline Dahlia Cav. & 10 & 6.17 \\
\hline Coreopsis L. & 7 & 10.36 \\
\hline Rudbeckia L. & 15 & 11.00 \\
\hline Tagetes L. & 11 & 5.40 \\
\hline Cosmos sulphureus Cav. & 7 & 4.00 \\
\hline Echinacea purpurea (L.) Moench & 3 & 1.45 \\
\hline \multicolumn{3}{|l|}{ Campanulaceae Juss. } \\
\hline Campanula L. & 3 & 1.98 \\
\hline \multicolumn{3}{|l|}{ Caprifoliaceae Juss. } \\
\hline Lonicera tatarica $\mathrm{L}$. & 8 & 4.20 \\
\hline $\begin{array}{l}\text { Weigela floribunda (Sieb. et Zucc.) } \\
\text { C. Koch. }\end{array}$ & 5 & 3.21 \\
\hline
\end{tabular}

Caryophyllaceae Juss.

\begin{tabular}{lcc}
\hline Gypsophila paniculata L. & 12 & 5.00 \\
\hline Crassulaceae J. St.-Hil. & & \\
\hline Sedum acre L. & 14 & 16.57 \\
\hline Ericaceae Juss. & & \\
\hline Rhododendron dauricum L. & 5 & 1.84 \\
\hline Fabaceae Lindl. & & \\
\hline
\end{tabular}

\begin{tabular}{lcc}
\hline Caragana arborescens Lam. & 3 & 1.98 \\
\hline Hydrangeacea Dumort. & & \\
\hline Deutzia scabra Thunb. & 2 & 2.62 \\
Philadelphus coronarius L. & 4 & 3.87 \\
\hline Lamiaceae Martinov & &
\end{tabular}

Lamiaceae Martinov

\begin{tabular}{lll}
\hline Stachys byzantina K. Koch & 5 & 3.21 \\
Salvia L. & 5 & 2.78 \\
\hline
\end{tabular}

Liliaceae Juss.

\begin{tabular}{lll}
\hline Tulipa L. & 3 & 1.74 \\
\hline
\end{tabular}

intended for broods. Thus, a continuance of blossom is needed from March to September. According to our data, it is not found in a number of parks, and less so at roadsides, in flowerbeds and garden squares. Therefore, the assortment of angiosperms does not provide the succession of flowering plants to sustain wild bees. Some plant species

\begin{tabular}{|c|c|c|}
\hline Plant taxa & 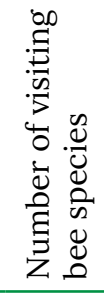 & 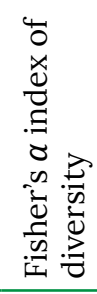 \\
\hline \multicolumn{3}{|l|}{ Magnoliaceae Juss. } \\
\hline Magnolia L. & 3 & 1.98 \\
\hline \multicolumn{3}{|l|}{ Malvacea Juss. } \\
\hline Malva L. & 7 & 2.76 \\
\hline \multicolumn{3}{|l|}{ Oleacea Hoffmanns. \& Link } \\
\hline Syringa L. & 3 & 2.38 \\
\hline \multicolumn{3}{|l|}{ Papaveraceae Juss. } \\
\hline Eschscholzia californica Cham. & 3 & 2.38 \\
\hline Papaver orientale L. & 3 & 5.45 \\
\hline \multicolumn{3}{|l|}{ Plantaginaceae Juss. } \\
\hline Digitalis purpurea L. & 1 & 0.427 \\
\hline \multicolumn{3}{|l|}{ Rosaceae Juss. } \\
\hline Cerasus erythrocarpa Nevski. & 12 & 7.18 \\
\hline $\begin{array}{l}\text { Chaenomeles japonica (Thunb.) Lindl. } \\
\text { ex Spach }\end{array}$ & 5 & 2.21 \\
\hline Crataegus Tourn. ex L. & 4 & 3.18 \\
\hline Malus P. Mill. & 7 & 4.00 \\
\hline Prunus L. & 4 & 1.13 \\
\hline Rosa L. & 4 & 2.75 \\
\hline Spiraea L. & 11 & 3.24 \\
\hline \multicolumn{3}{|l|}{ Sapindaceae Juss. } \\
\hline Aesculus hippocastanum L. & 8 & 5.51 \\
\hline \multicolumn{3}{|l|}{ Tamaricaceae Link } \\
\hline Tamarix ramosissima Ldb. & 6 & 3.15 \\
\hline \multicolumn{3}{|l|}{ Asparagaceae Juss. } \\
\hline Hosta Tratt. & 5 & 2.13 \\
\hline \multicolumn{3}{|l|}{ Bignoniaceae Juss. } \\
\hline Catalpa Scop. & 3 & 3.16 \\
\hline
\end{tabular}

bloom only in early spring, others only in summer. Only by combining plants with varying periods of flowering, it is possible to sustain wild bees with good-quality nutrition resources. In Kyiv, the most common and attractive for bees ornamental plants flower from the end of April till the middle of August (Fig. 5). This fact indicates the incompleteness 


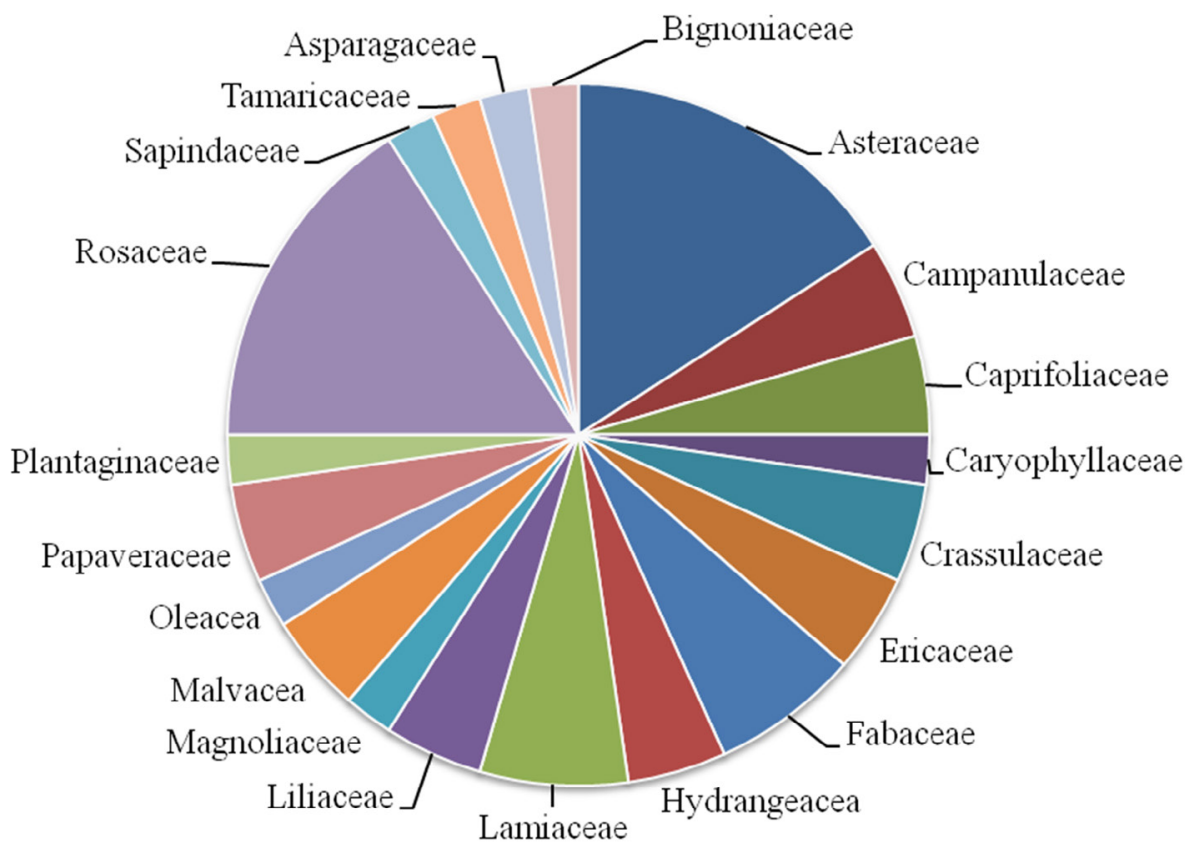

Figure 4. The relative share of most common ornamental plant families in the diet of wild bees in urban areas.

of feeding resources for bees in early spring and autumn.

\section{Discussion}

Urban ornamental plants are usually introduced species. The nectar they produce may contain metabolites, which are unattractive, unusable, and even poisonous to bees due to the narrow ranges of feeding preferences of the latter (Novotny \& Basset, 2005; Dyer et al., 2007). An example of such a plant is Tilia tomentosa Moench, with nectar that can cause mass mortality of bumblebees (Koch et al., 2017; Jacquemart et al., 2018). We would like to note that this plant is rarely used in green areas of Kyiv, only sometimes in residential areas and collections of botanical gardens and arboretums.

Double-flowered plants are widely used for ornamentation of green areas and present another problem for the foraging bees. Such plants are less attractive for pollinators due to lower production of nectar and accessibility of flowers (Comba et al., 1999; Corbet et al., 2001). According to our data, double-flowered cultivars of the genera Dahlia, Tagetes, Paeonia L., and Rosa were indeed less attractive for bees compared to the cultivars with simple flowers. Among other ornamental and widely used plants, cultivars of Petunia Juss. had low value for bees. Their flowers produce nectar and pollen in low quantities, and their deep and narrow corollas limit the access to the flower in general. Varieties and cultivars of Ageratum L., Hydrangea L., Viola $\times$ wittrockiana, and Begonia L. are also unattractive for bees.

On the other hand, there are such widely grown, aggressive introduced species as Robinia pseudoacacia L., Amorpha fruticosa L., Solidago canadensis L., S. gigantea Aiton and Asclepias syriaca L. They are considered to be quality honey plants, rich with nectar and pollen, with long periods of flowering and at times presenting the only foraging resource for bees. However, their ability to displace other plants has negative effect on the ecosystem as a whole (Salisbury et al., 2015; Baker \& Potter, 2018; Jachuła et al., 2020). Therefore, using species of the natural flora of Ukraine to maintain green areas is preferable, because that would also sustain the populations of rare and specialized species of wild bees (Gnatiuk \& Gaponenko, 2018). We think that using species of the genera Tamarix and Rhododendron (in particular, R. dauricum) would be advantageous in the maintenance of urban green areas because these plants are of high ornamental value and produce nectar and pollen for many wild bee 


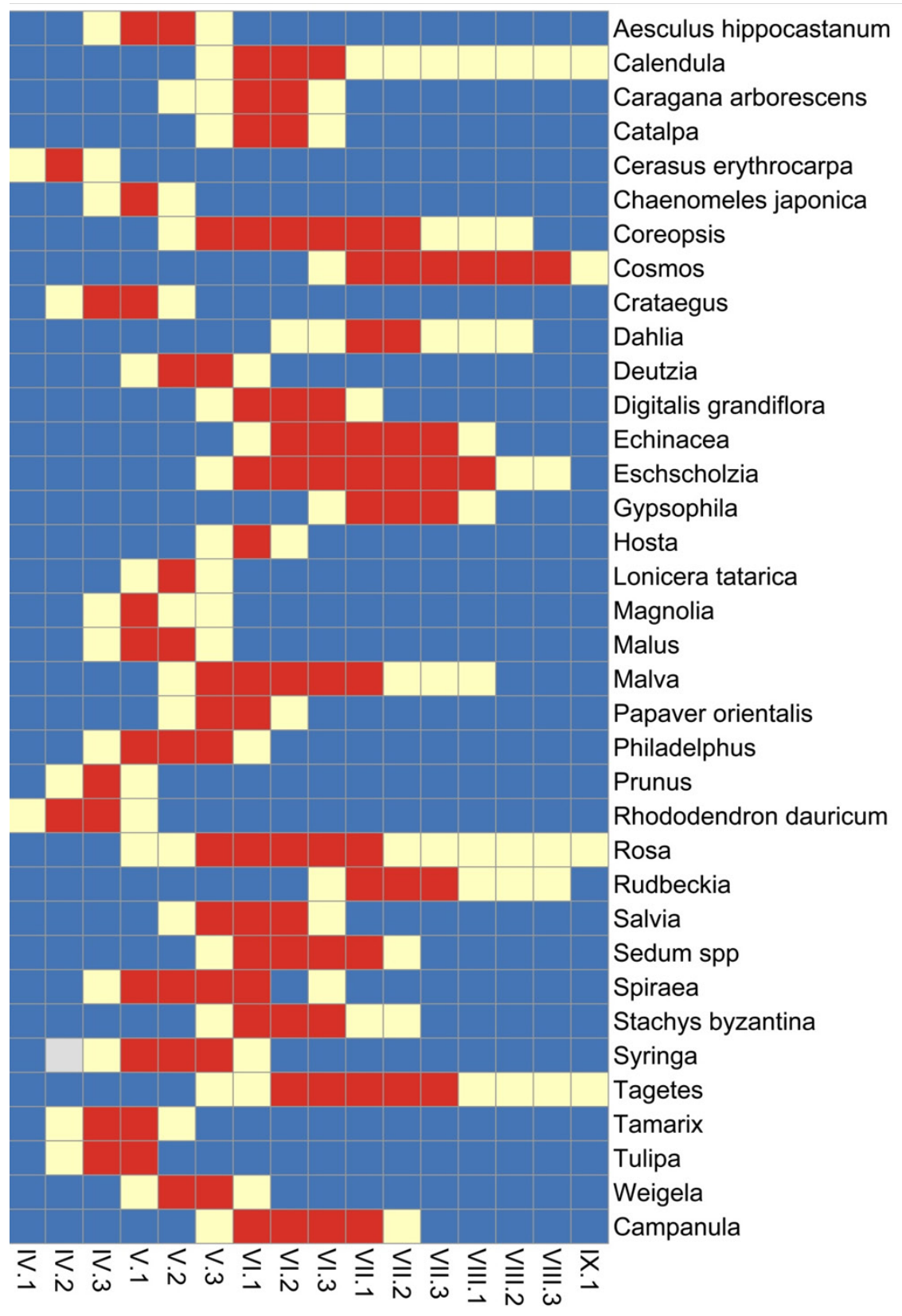

Figure 5. Periods of the blossom of ornamental plants, which are most common and attractive for bees in Kyiv: $\square$ - no flowering; $\square$ - beginning and ending of anthesis; $\square$ - the main period of anthesis (IV-IX months; 1-3 - first, second and third 10-day periods).

species in spring. Similar recommendations concerning the species mentioned above and species of the genus Lonicera and to a lesser degree, Deutzia, have been made for the maintenance of green areas in other European cities (Bagatska \& Romanenko, 2011; Jachuła et al., 2019; Masierowska, 2006).

\section{Conclusions}

Parks, botanical gardens, garden squares, and other green areas sustain the biological diversity in cities. For pollinators, whose populations face a worldwide decline, the flowering plants of green areas are especially important. We examined more than 35 species of plants of 20 families and observed the highest bee diversity on plants of the families Asteraceae, Rosaceae, and Lamiaceae. The most attractive plant species under study belong to the genera Aesculus, Rhododendron, Rudbeckia, Sedum, Gypsophila, Prunus, Malus, Tagetes, Spiraea, Lonicera, and Tamarix. Certain plant species, for example, from the genera Malva, Campanula, Stachys, and 
Digitalis attract specialized bee species. Ornamental angiosperms also provide pollen and nectar to species listed in the Red Data Book of Ukraine, Bombus argillaceus and Xylocopa valga.

In our opinion, the plants used in urban green areas should not have decorative value only but also provide pollen and nectar to the wild bees of urban landscapes. To ensure the excellent nutritive resources for bees, the assortment of flowering plants should be continuous, and cultivars and varieties with simple flowers should be a preference for the green areas. Of particular interest are earlyflowering species and plants which bloom in autumn. Using plant species with lowproductive flowers which are inaccessible for insects should be limited. Introduced plants, which are tolerant of urban conditions and actively produce seeds and self-propagate, should be avoided.

It should be noted that the assortment of ornamental plants used in urban green areas is continuously growing. Thus the studies of trophic relations between the wild bees (and insects in general) have to be continued. That would provide scientific recommendations for the selection of species and cultivars of esthetically pleasing plants that ensure the survival of many groups of insects in urban conditions.

\section{References}

Acar, C., Acar, H., \& Eroğlu, E. (2007). Evaluation of ornamental plant resources to urban biodiversity and cultural changing: a case study of residential landscapes in Trabzon city (Turkey). Building and Environment, 42, 218-229. https://doi.org/10.1016/j.buildenv.2005.08.030

Bagatska, O. M., \& Romanenko, T. A. (2011). Future use of the genus Tamarix $\mathrm{L}$. in gardening settlements. Scientific Bulletin of Ukrainian National Forestry University, 21(16), 301-306. (In Ukrainian)

Baker, A. M., \& Potter, D. A. (2018). Colonization and usage of eight milkweed (Asclepias) species by monarch butterflies and bees in urban garden settings. Journal of Insect Conservation, 22(3-4), 405418. https://doi.org/10.1007/s10841-018-0069-5

Banaszak-Cibicka, W., \& Żmihorski, M. (2012). Wild bees along an urban gradient: winners and losers. Journal of Insect Conservation, 16(3), 331343. https://doi.org/10.1007/s10841-011-9419-2
Cherevchenko, T. M., Moroz, P. A., Kuznetsov, S. I., \& Muzychuk G. M. (1999). Plant diversity conservation problems ex situ. Plant Introduction, 1, 7-13. (In Ukrainian). https://doi.org/10.5281/ zenodo.3367330

Cherevchenko, N. M., \& Kuznetsov, S. I. (2003). The biodiversity of trees and shrubs in great sites and its provident (on the example of Kiev). Scientific Bulletin of Ukrainian National Forestry University, 13(5), 22-27. (In Ukrainian)

Chiesura, A. (2004). The role of urban parks for the sustainable city. Landscape and Urban Planning, 68(1), 129-138. https://doi.org/10.1016/j. landurbplan.2003.08.003

Comba, L., Corbet, S. A., Hunt, L., \& Warren, B. (1999). Flowers, nectar and insect visits: Evaluating British plant species for pollinatorfriendly gardens. Annals of Botany, 83(4), 369-383. https://doi.org/10.1006/anbo.1998.0835

Corbet, S. A., Bee, J., Dasmahapatra, K., Gale, S., Gorringe, E., La Ferla, B., Moorhouse, T., Trevail A., Van Bergen, Y., \& Vorontsova, M. (2001). Native or exotic? Double or single? Evaluating plants for pollinator-friendly gardens. Annals of Botany, 87(2), 219-232. https://doi. org/10.1006/anbo.2000.1322

da Rocha-Filho, L. C., Ferreira-Caliman, M. J., Garófalo, C. A., \& Augusto, S. C. (2018). A specialist in an urban area: are cities suitable to harbour populations of the oligolectic bee Centris (Melacentris) collaris (Apidae: Centridini)? Annales Zoologici Fennici, 55(1-3), 135-149. https://doi. org/10.5735/086.055.0101

Dearborn, D. C., \& Kark, S. (2010). Motivations for conserving urban biodiversity. Conservation Biology, 24(2), 432-440. https://doi.org/10.1111/ j.1523-1739.2009.01328.x

Dormann, C. F. (2011). How to be a specialist? Quantifying specialisation in pollination networks. Network Biology, 1(1), 1-20. Retrieved from https:// www.semanticscholar.org/paper/How-to-be-aspecialist-Quantifying-specialisation-Dormann/3 4459dae080790d7aafe9bb1e1 db9e045b78bde3

Dormann, C. F. (2020). Using bipartite to describe and plot two-mode networks in R. Freiburg: University of Freiburg. Retrieved from https://cran.rproject.org/web/packages/bipartite/vignettes/ Intro2bipartite.pdf

Doyko, N. (2012). Floral park unit "Alexandria". Agrobiology, 8, 72-74 (In Ukrainian)

Dyer, J. S., Halterman, J. R., Hunner, G. J., \& Muehlbach, G. B. (2007). Method and system of evaluating performance of a crop. U.S. Patent No. 7,184,892. Washington, DC: U.S. Patent and Trademark Office. Retrieved from https://insight. rpxcorp.com/pat/US7184892B1 
Erickson, E., Adam, S., Russo, L., Wojcik, V., Patch, H. M., \& Grozinger, C. M. (2020). More than meets the eye? The role of annual ornamental flowers in supporting pollinators. Environmental Entomology, 49(1), 178-188. https://doi.org/10.1093/ee/nvz133

Fisher, R. A., Corbet, A. S., \& Williams, C. B. (1943). The relation between the number of species and the number of individuals in a random sample of an animal population. The Journal of Animal Ecology, 12(1), 42-58. https://doi.org/10.2307/1411

Garbuzov, M., \& Ratnieks, F. L. (2014). Quantifying variation among garden plants in attractiveness to bees and other flower-visiting insects. Functional Ecology, 28(2), 364-374. https://doi. org/10.1111/1365-2435.12178

Garbuzov, M., Alton, K., \& Ratnieks, F. L. (2017). Most ornamental plants on sale in garden centres are unattractive to flower-visiting insects. Peerf, 5, e3066. https://doi.org/10.7717/peerj.3066

Gathmann, A., \& Tscharntke, T. (2002). Foraging ranges of solitary bees. Journal of Animal Ecology, 71(5), 757-764. https://doi.org/10.1046/j.13652656.2002.00641.x

Gnatiuk, A. M., \& Gaponenko, M. B. (2018, June 1215). Prospects for the use of herbaceous species of flora of Ukraine in landscaping and landscape architecture. In Proceedings of the $X$ International Scientific Conference "Landscape Architecture in Botanical Gardens and Arboretums" (pp. 48-52). Kyiv. (In Ukrainian)

Hammitt, W. E. (2002). Urban forests and parks as privacy refuges. Journal of Arboriculture, 28(1), 19-26.

Hatalska, N., \& Kryvenko, O. (2012). Compex estimation of plantings on the territory of educational building NUBiP of Ukraine. Agrobiology, 8, 50-54. (In Ukrainian)

Hausmann, S. L., Petermann, J. S., \& Rolff, J. (2016). Wild bees as pollinators of city trees. Insect Conservation and Diversity, 9(2), 97-107. https:// doi.org/10.1111/icad.12145

Hennig, E. I., \& Ghazoul, J. (2011). Plant-pollinator interactions within the urban environment. Perspectives in Plant Ecology, Evolution and Systematics, 13(2), 137-150. https://doi. org/10.1016/j.ppees.2011.03.003

Honchar, H. Y. (2017). Species composition and ecological features of wild bees (Hymenoptera: Apoidea) of the Dnipro Islands in Kyiv. The Kharkov Entomological Society Gazette, 25(2), 11-21. (In Russian)

Honchar, H. Y., \& Gnatiuk, A. M. (2018). The diversity of wild bees (Hymenoptera, Apoidea) in M.M. Gryshko National Botanical Garden of the NAS of Ukraine. The Kharkov Entomological Society Gazette, 26(2). (In Ukranian). https://doi. org/10.36016/KhESG-2018-26-2-5
Jachuła, J., Denisow, B., \& StrzałkowskaAbramek, M. (2019). Floral reward and insect visitors in six ornamental Lonicera species plants suitable for urban bee-friendly gardens. Urban Forestry \& Urban Greening, 44, 126390. https://doi.org/10.1016/j.ufug.2019.126390

Jachuła, J., Denisow, B., \& StrzałkowskaAbramek, M. (2020). Does an invader have a bright side? Floral reward in two Solidago species. Journal of Apicultural Research. https://doi.org/1 0.1080/00218839.2019.1703086

Jacquemart, A. L., Moquet, L., Ouvrard, P., QuetinLeclercq, J., Hérent, M. F., \& Quinet, M. (2018). Tilia trees: Toxic or valuable resources for pollinators?. Apidologie, 49(5), 538-550. https:// doi.org/10.1007/s13592-018-0581-3

Klein, A. M., Vaissiere, B. E., Cane, J. H., SteffanDewenter, I., Cunningham, S. A., Kremen, C., \& Tscharntke, T. (2007). Importance of pollinators in changing landscapes for world crops. Proceedings of the Royal Society B: Biological Sciences, 274(1608), 303-313. http://doi.org/10.1098/ rspb.2006.3721

Klymenko, H. (2012). Bioecological characteristics of planting assortment of tree and shrub plantations in Kyiv. Bulletin SNBG 104, 58. (In Ukrainian)

Koch, H., \& Stevenson, P. C. (2017). Do linden trees kill bees? Reviewing the causes of bee deaths on silver linden (Tilia tomentosa). Biology Letters, 13(9), 20170484. http://doi.org/10.1098/ rsbl.2017.0484

Lesnik, O. M., \& Girs, O. A. (2015). Analysis of providing the city of Kyiv with green space. Ukrainian Journal of Forest and Wood Science, 216(1), 15-21. (In Ukrainian)

Lowenstein, D. M., Matteson, K. C., \& Minor, E. S. (2019). Evaluating the dependence of urban pollinators on ornamental, non-native, and 'weedy' floral resources. Urban Ecosystems, 22(2), 293-302. https://doi.org/10.1007/s11252-0180817-z

Magurran, A. E. (2013). Measuring biological diversity. Wiley-Blackwell.

Masierowska, M. L. (2006). Floral reward and insect visitation in ornamental deutzias (Deutzia spp.), Saxifragaceae sensu lato. Journal of Apicultural Research, 45(1), 13-19. https://doi.org/10.1080/0 0218839.2006 .11101306

Matiashuk, R. K., Goncharenko, I. V., Tkachenko, I. V., Prokopuk, Y. S., \& Shchur, K. Y. (2015). Taxonomic composition and spatial structure of the elements of landscaping park "Feofaniya". Ecology and Noospherology, 26, (3-4), 21-29. (In Ukrainian) 
Melezhyk, O.V. (2015). Assessment of the status of the monuments of landscape art in Kyiv. Common Environmental Safety, 5, 110. (In Ukrainian)

Mexia, T., Vieira, J., Príncipe, A., Anjos, A., Silva, P., Lopes, N., Freitas, C., SantosReisa, M., Correia, O., Branquinhoa, C., \& Pinho, P. (2018). Ecosystem services: Urban parks under a magnifying glass. Environmental research, 160, 469-478. https://doi.org/10.1016/j. envres.2017.10.023

Novotny, V., \& Basset, Y. (2005). Host specificity of insect herbivores in tropical forests. Proceedings of the Royal Society B: Biological Sciences, 272 (1568), 1083-1090. https://doi.org/10.1098/ rspb.2004.3023

Oleksiychenko, N. O., \& Breus, N. Y. (2013). Assessment of the decorative nature of beautiful flowering shrubs that bloom in the season "height of spring". Forestry and Landscape Gardening, 3, 9841. (In Ukrainian). Retrieved from http://journals.nubip.edu.ua/index.php/Lis/ article/view/9841

Pesenko, Y. A. (1982). Principles and methods of quantitative analysis in faunistic researches. Moskva: Nauka. (In Russian)

Pikhalo, O. V. (2014). Organization of the territory of urban single-level transport interchanges (on the example of the Obolon district of Kyiv). Forestry and Landscape Gardening, 4, 9969. (In Ukrainian). Retrieved from http://journals.nubip.edu.ua/ index.php/Lis/article/view/9969

Potts, S. G., Biesmeijer, J. C., Kremen, C., Neumann, P., Schweiger, O., \& Kunin, W. E. (2010). Global pollinator declines: trends, impacts and drivers. Trends in Ecology \& Evolution, 25(6), 345-353. http://doi.org/10.1016/j. tree.2010.01.007

R Core Team. (2014). R: A language and environment for statistical computing. Vienna, Austria: R Foundation for Statistical Computing. Retrieved from https://www.R-project.org

Radchenko, V. G. (2009). Dzhmil hlynystiy. Bombus (Megabombus) argillaceus Smith, 1854. In I. A. Akimov (Ed.), The Red Data Book of Ukraine. Animals (p. 269). Kyiv: Global Consulting. (In Ukrainian)

Radchenko, V. G., Filatov, M. O., \& Ivanov, S. P. (2009). Ksylokopa (bdzhola-tesliar) zvychayna. Xylocopa (Xylocopa) valga Gerstaecker, 1872. In I. A. Akimov (Ed.), The Red Data Book of Ukraine. Animals (p. 264). Kyiv: Global Consulting. (In Ukrainian)
Radchenko, V., \& Honchar, H. (2019). Species diversity of wild bees (Hymenoptera: Apoidea) in parks of Kyiv. Bulletin of Taras Shevchenko National University of Kyiv, Series Biology, 78(2), 40-49. (In Ukranian)

Rogovskiy, S. V. (2013). Experience in the creation and maintenance of green spaces in European cities and its use in Ukraine. Ukrainian Journal of Forest and Wood Science, 187(1), 126-134. (In Ukrainian)

Rubtsova, O. L. (2006). Ukrainian botanical, acclimatization gardens and dendroparks - centers of introduction of Rosa L. representatives. Plant Introduction, 1, 3-10. https://doi.org/10.5281/zenodo.2567187

Salisbury, A., Armitage, J., Bostock, H., Perry, J., Tatchell, M., \& Thompson, K. (2015). Editor's choice: Enhancing gardens as habitats for flower-visiting aerial insects (pollinators): Should we plant native or exotic species? Journal of Applied Ecology, 52(5), 1156-1164. https://doi. org/10.1111/1365-2664.12499

Sanderson, E. W., \& Huron, A. (2011). Conservation in the city. Conservation Biology, 25, 421- 423. https://doi.org/10.1111/j.15231739.2011.01683.x

Sikora, A., Michołap, P., \& Sikora, M. (2020). What kind of flowering plants are attractive for bumblebees in urban green areas? Urban Forestry \& Urban Greening, 48,126546. https:// doi.org/10.1016/j.ufug.2019.126546

Smitley, D. (2018). Marketing the ecosystem services provided by food plants for pollinators. In Proceedings of the 2017 Annual Meeting of the International Plant Propagators' Society. Acta Horticulturae, 1212, 101-102. https://doi. org/10.17660/ActaHortic.2018.1212.20

Somme, L., Moquet, L., Quinet, M., Vanderplanck, M., Michez, D., Lognay, G., \& Jacquemart, A. L. (2016). Food in a row: urban trees offer valuable floral resources to pollinating insects. Urban Ecosystems, 19, 11491161. https://doi.org/10.1007/s11252-0160555-Z

Winfree, R., Aguilar, R., Vázquez, D. P., LeBuhn, G., \& Aizen, M. A. (2009). A metaanalysis of bees' responses to anthropogenic disturbance. Ecology, 90(8), 2068-2076. http:// doi.org/10.1890/08-1245.1 


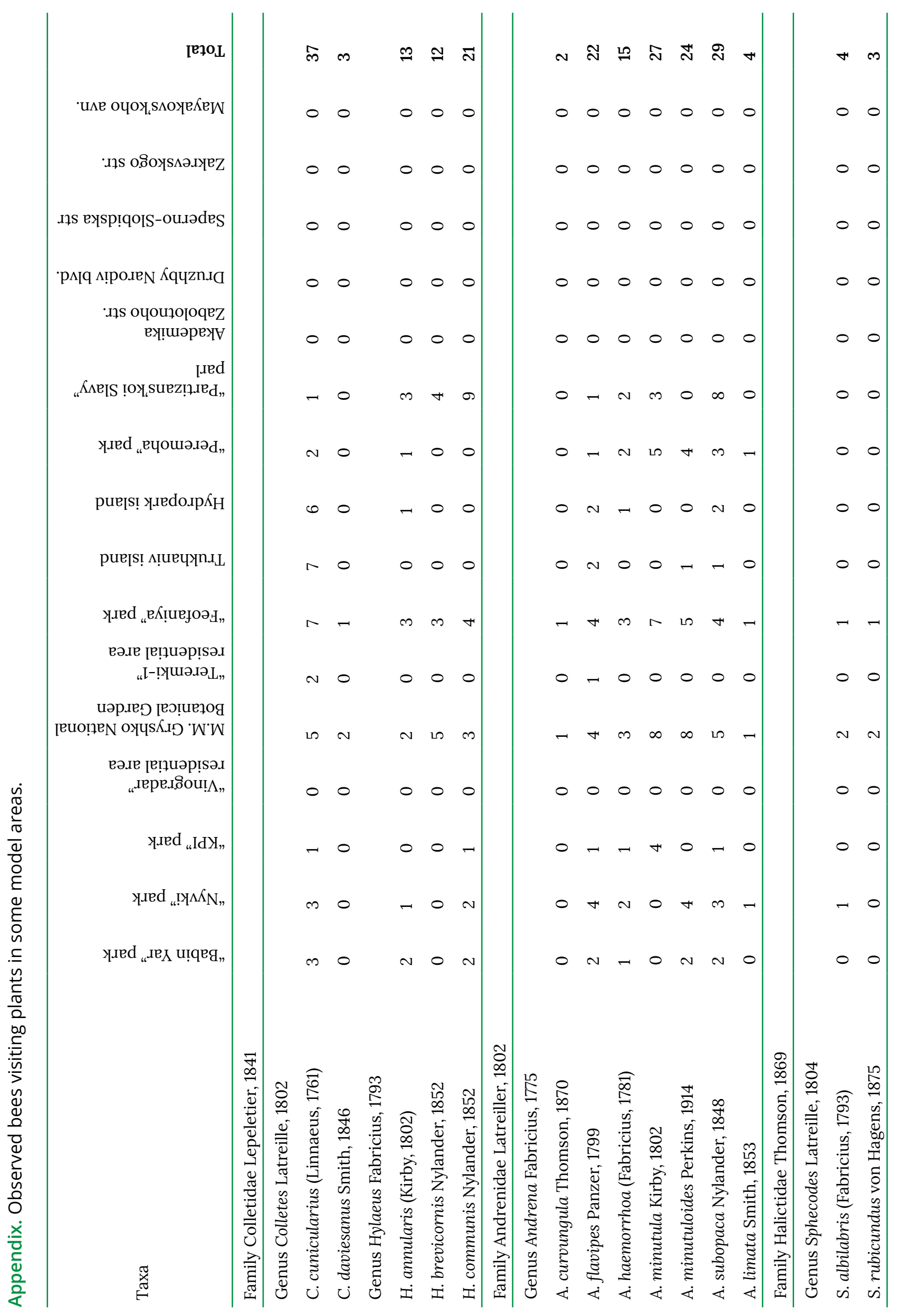




\begin{tabular}{|c|c|c|c|c|c|c|c|c|c|c|c|c|c|c|c|c|c|c|c|}
\hline$\left[\mathrm{e} 7 \mathrm{C}_{\downarrow}\right.$ & & & $\infty$ & ת & $N$ & & 윽 & 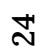 & & $m$ & مו & & ి्లి & $\boldsymbol{H}$ & 암 & ๓ి & พ & & 0 \\
\hline 'U & & & 0 & 0 & 0 & & 0 & 0 & & 0 & 0 & & 0 & 0 & 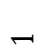 & 0 & $N$ & & 0 \\
\hline 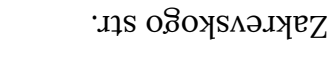 & & & 0 & 0 & 0 & & 0 & 0 & & 0 & 0 & & 0 & 0 & $m$ & 0 & L & & 0 \\
\hline ıłs exsp!qois-ouıədes & & & 0 & 0 & 0 & & 0 & 0 & & 0 & 0 & & 0 & 0 & 0 & 0 & $m$ & & 0 \\
\hline 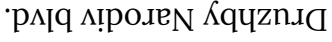 & & & 0 & 0 & 0 & & 0 & 0 & & 0 & 0 & & 0 & 0 & $N$ & 0 & $m$ & & 0 \\
\hline еч!щшрех甘 & & & 0 & 0 & 0 & & 0 & 0 & & 0 & 0 & & 0 & 0 & 0 & $N$ & 0 & & 0 \\
\hline 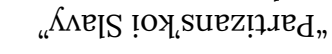 & & & 0 & 0 & - & & $N$ & L & & 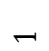 & 0 & & $\Lambda$ & 0 & $\Lambda$ & - & 0 & & 0 \\
\hline 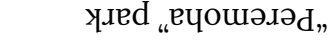 & & & 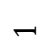 & 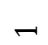 & - & & $N$ & $m$ & & 0 & - & & L & 0 & $\infty$ & L & 0 & & 0 \\
\hline pue[s! গ.ıedo.sp $\kappa_{\mathrm{H}}$ & & & 0 & 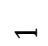 & 0 & & 0 & 0 & & 0 & 0 & & $N$ & 0 & $N$ & 0 & 0 & & 0 \\
\hline 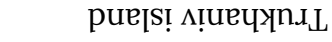 & & & 0 & 0 & 0 & & 0 & 0 & & 0 & $\nabla$ & & $N$ & 0 & $N$ & 0 & 0 & & 0 \\
\hline 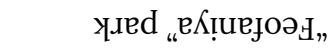 & & & $m$ & - & 0 & & $N$ & $\sim$ & & - & 0 & & L & $N$ & L & 10 & 0 & & $N$ \\
\hline 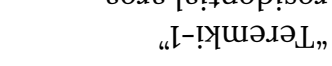 & & & 0 & 0 & 0 & & 0 & 0 & & 0 & 0 & & 0 & 0 & 0 & 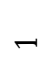 & $m$ & & 0 \\
\hline 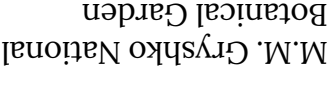 & & & $N$ & - & 0 & & $N$ & $a$ & & - & 0 & & $\nabla$ & $\sim$ & H & L & - & & H \\
\hline 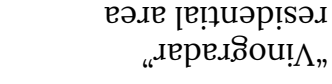 & & & 0 & 0 & 0 & & 0 & 0 & & 0 & 0 & & 0 & 0 & 0 & $N$ & $m$ & & 0 \\
\hline Yued “IdX” & & & 0 & 0 & 0 & & 0 & 0 & & 0 & 0 & & 0 & 0 & 0 & 0 & 0 & & 0 \\
\hline Yued "I! $\left[\Lambda \Lambda_{\mathrm{N}}\right.$, & & & $N$ & 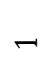 & 0 & & $N$ & 0 & & 0 & 0 & & $m$ & 0 & $m$ & $a$ & L & & 0 \\
\hline xied “Iе & & & 0 & 0 & 0 & & 0 & 0 & & 0 & 0 & & $N$ & 0 & $m$ & $m$ & L & & 0 \\
\hline$\underset{\substack{\tilde{x} \\
\tilde{x}}}{\pi}$ & 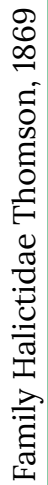 & 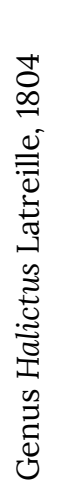 & 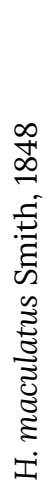 & 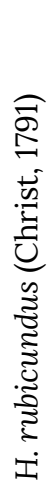 & 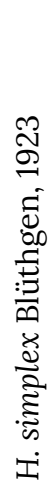 & 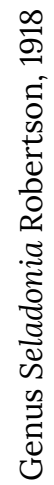 & 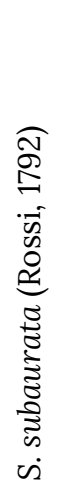 & 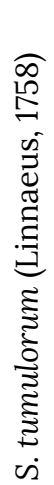 & 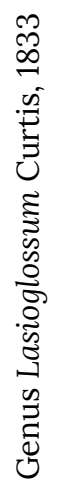 & 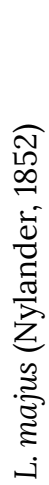 & 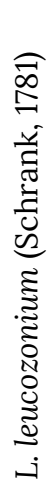 & 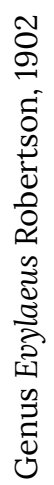 & 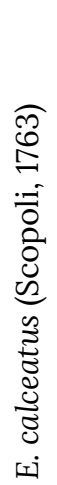 & 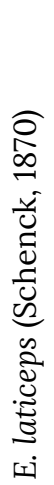 & 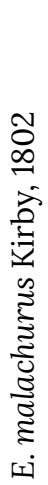 & 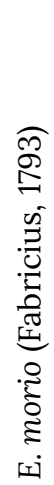 & 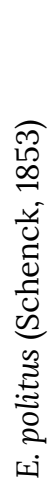 & 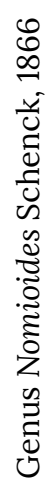 & 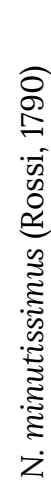 \\
\hline
\end{tabular}




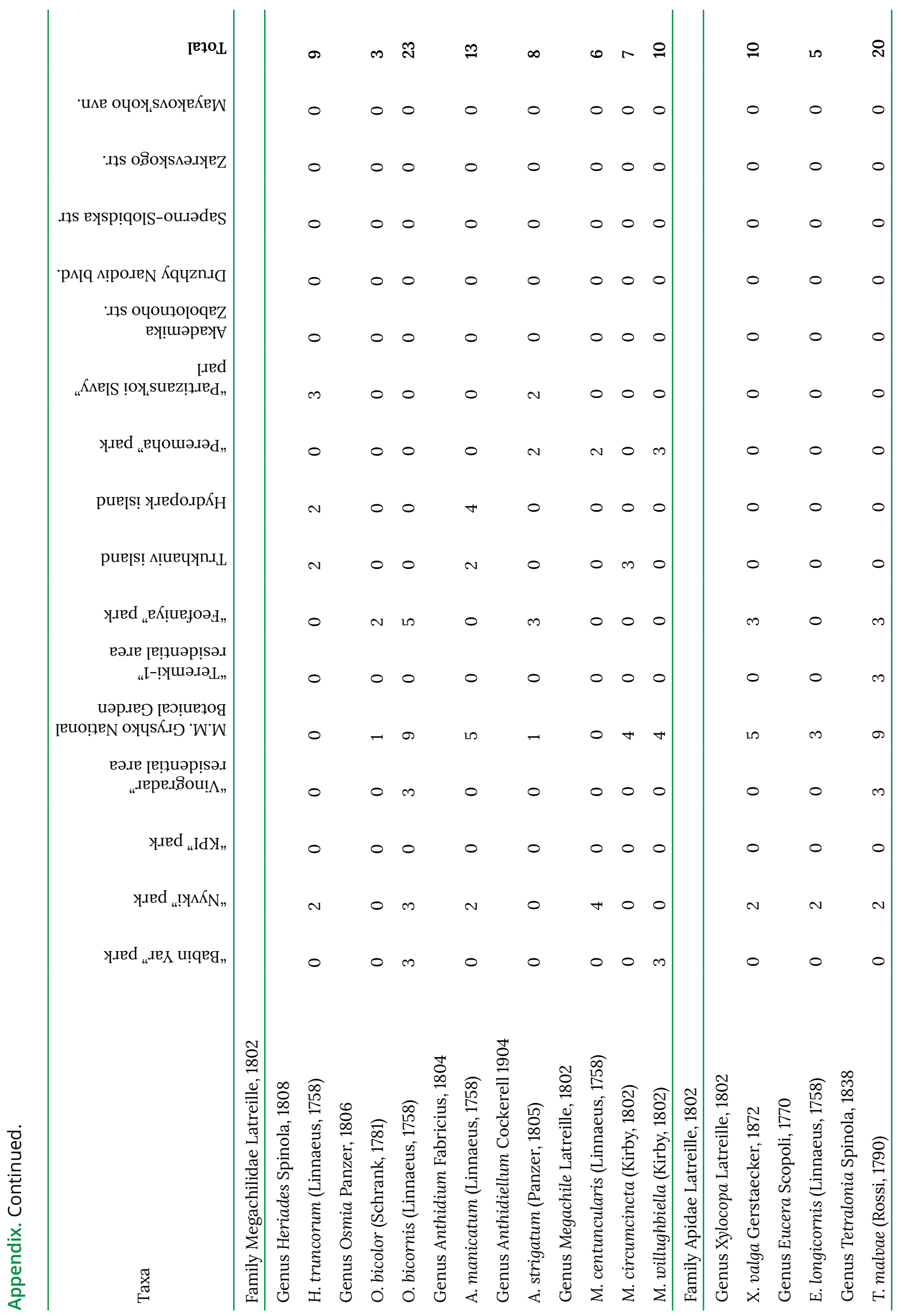




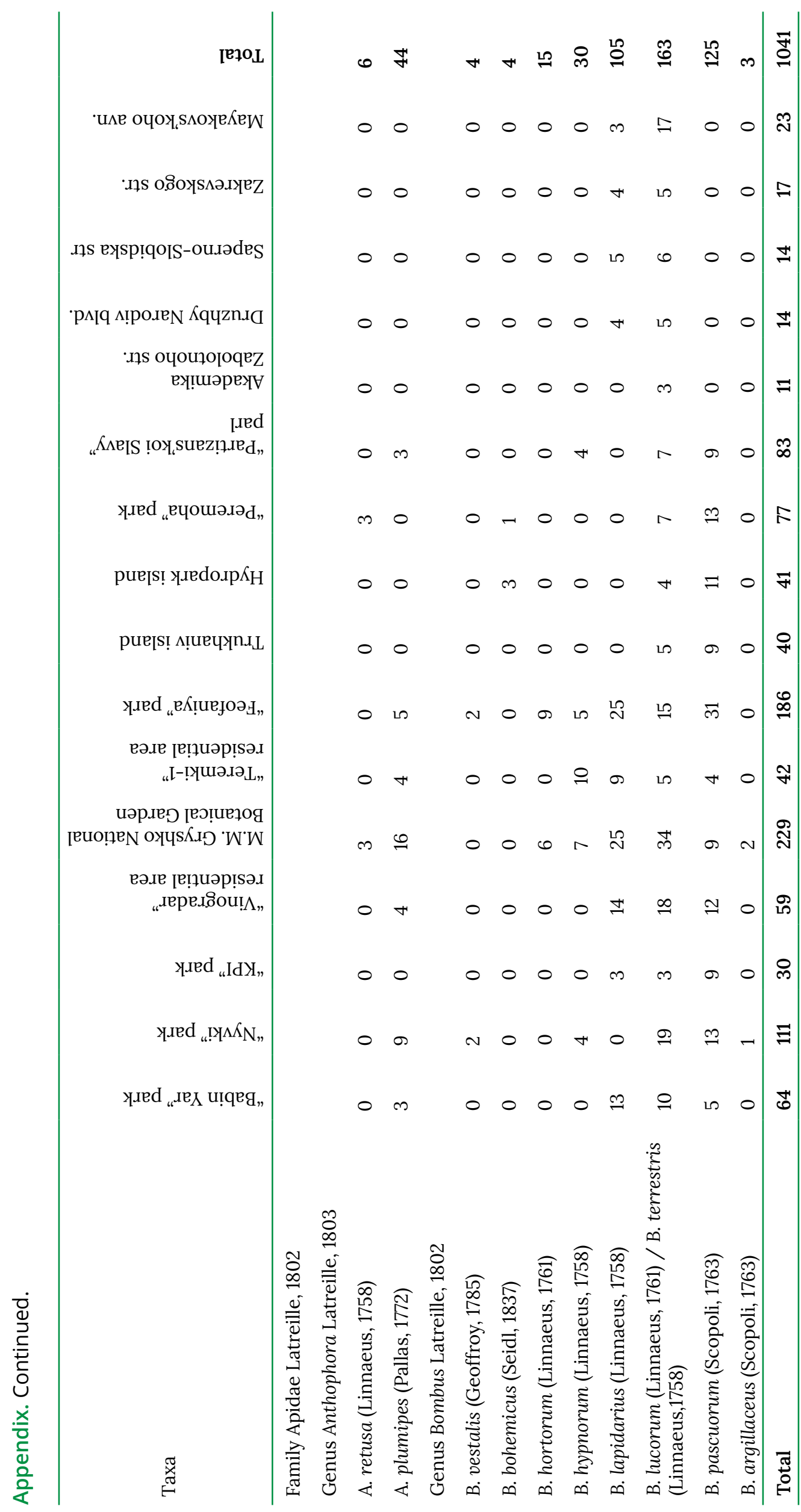




\section{Роль зелених насаджень міста у збереженні диких бджіл (Hymenoptera, Apoidea)}

Г.Ю. Гончар ${ }^{1}$, А.М. Гнатюк ${ }^{2}$

${ }^{1}$ Інститут еволюційної екології НАН України, вул. Лебедєва, 37, Київ, 03143, Україна; apantova@ukr.net

${ }^{2}$ Національний ботанічний сад імені М.М. Гришка НАН України, вул. Тімірязєвська, 1, Київ, 01014, Україна; colchicum@i.uа

Метою нашого дослідження було визначення привабливості та ролі зелених квітучих насаджень міста Києва для підтримки та збереження популяцій диких бджіл (Hymenoptera, Apoidea). Об'єктом дослідження були найпоширеніші квітучі насадження міста та дикі бджоли, які відвідували їхні квітки протягом сезону квітування для збору пилку та харчування нектаром. Територія дослідження охоплювала міські парки, НБС ім. М.М. Гришка, зелені насадження житлових кварталів, узбіч, тощо (загалом 16 пунктів спостереження та відбору). Відбір комах здійснювався за загальноприйнятою методикою - індивідуальним відловом на квітках протягом весняно-літнього сезону 2012-2018 років. На основі цих спостережень будували графічне зображення трофічних зв'язків бджіл із відповідними рослинами, а також обраховували індекс різноманіття відвідувачів для рослин. На основі фенологічних даних будували графік періоду квітування основних рослин. У результаті обстеження зелених насаджень міста виявлено найбільш привабливі для бджіл декоративні насадження із деревних, чагарникових та трав'янистих видів рослин, що складається 3 понад 35 таксонів та близько 20 родин. Серед найбільш привабливих для комах виділено такі роди рослин як Rudbeckia, Sedum, Gypsophila, Cerasus, Tagetes, Spiraea, Lonicera, Aesculus, та деякі інші. Протягом веснянолітнього сезону відбувається зміна квітучих рослин, що необхідно враховувати при озелененні. У кожен період квітування певні види $\epsilon$ привабливими для комах, так упродовж весняного періоду - Prunus, Rhododendron, Crataegus, Aesculus, у літній - більшість представників родини Asteraceae, на кінець літа та початок осені залишається незначне різноманіття рослин, але у цей період основна льотна активність більшості диких бджіл вже завершується. Загалом, досліджені декоративні рослини приваблюють не тільки найбільш поширені види диких бджіл, але і спеціалізовані та рідкісні види, наприклад Bombus argillaceus та Xylocopa valga, що внесені до Червоної Книги України. Нами встановлено, що квітучі зелені насадження, які складаються із декоративних деревних, чагарникових та трав'янистих форм відіграють значну роль у живленні багатьох видів диких бджіл, що сприяє збереженню та підтримці популяцій цих комах у міських умовах. 